\title{
Field Study on the Two Mite Species; Hemisarcoptes coccophagus Meyer (Astigmata: Hemisarcoptidae) and Phyllotetranychus aegyptiacus Sayed (Prostigmata: Tenuipalpidae) on Two Varieties of Date Palm Trees at Giza Governorate
}

\author{
Sawsan G. Radwan and Angel R. Attia \\ Plant Protection Research Institute, Agricultural Research Center, Dokki, Giza, Egypt
}

\begin{abstract}
Field study was carried out on the predaceous mite, Hemisarcoptes coccophagus Meyer and the phytophagous mite, Phyllotetranychus aegyptiacus Sayed associated with the diaspidid, Fiorinia phoenicis Balachowsky infesting two varieties (Semany and Zaghlol) of date palm trees at Giza governorate during the period from mid April 2012 to mid May 2013.Population of $F$. phoenicis was noted all over the year being low from $1^{\text {st }}$ November. Its population was recorded on Semany and Zaglol variety averaging 67.0 and 76.3 individuals/sq. inch showing highly significant difference as Zaghlol was favor for the prey.Population of nymphs and adults of $H$. coccophagus, was noted in large numbers from mid April to $1^{\text {st }}$ August. Its means all over the period of study was 10.3 and 11.8 individuals/sq. inch on Semany and Zaghlol with significant difference between records of the two varieties showing Zaghlol to be favor for the predaceous mite associated with its prey, $F$. phoenicis. The highest population of nymhs and adults of $P$. aegyptiacus was recorded in mid December; no individuals were recorded during the period from July to mid November. Means of P. aegyptiacus nymphs and adults on Semany and Zaghlol were 2.7 and 5.1 individuals / sq. inch showing Zaghlol to be favored for the phytophagus mite.
\end{abstract}

Key Words: Hemisar:optes coccophagus, Phyllotetranychus aegyptiacus, Fiorinia phoenicis, date palm.

\section{INTRODUCTION}

The date palm Phoenix dactylifera $\mathrm{L}$. is infested with many insect pests. Recently the diaspidid, Fiorinia phoenicis infested date palm leaflets and became the main scale insect attacking date palm in many Egyptian governorates; North Sinai (Gabbour and Mohammad, 2010), Giza (Elwan, et al., 2011), Qalubyia (Radwan, 2012), Cairo, Beni-Suef and Behira (Attia 2012).

Mites of genus Hemisarcoptes have been recognized as effective generalized predators of diaspidids associated with many genera of host scale insects (Shimer, 1868). Hemisarcoptes coccophagus acted as a most efficient predator of the date palm scale, Parlatoria blanchardii (Targioni Tozzetti) in the hot, dry climate of the Sahel region of Niger (Kaufmann, 1977).

The preferred diaspidid prey for Hemisarcoptes mites that recorded on different fruit trees are Hemiberlesia rapax (Comstock), $H$. latania (Signort) and Aspidiotus nerii Bouché on kiwi fruit and Shelter trees (Hill et al., 1993), Parlatoria pergandii Comstock and $P$. cinerea Chou on grape fruit and orange orchards ( Izraylevich and Gerson 1993), Lepedosaphes ulmi (Linnaeus) on apple trees (Erol and Yasar, 1999), Aspidiotus nerrii Bouché Lepidosaphes ulmi (Linnaeus) and Parlatoria oleae (Colveé) on olive tries (Stathas et al., 2005), Aonidiella aurantii (Mask) on citrus orchards
(Sorribas and Garcia, 2008), and Aulacaspis tubercularis (Newsteasd) on mango trees (Attia et al., 2012).

- In this investigation, $H$. coccophagus was recorded as a predator of the diaspidid, Fiorinia phoenicis Balachowsky for the first time and the tenuipalpid mite, Phyllotetranychus aegyptiacus Sayed infesting two varieties of date palm trees.

Phyllotetranychus aegyptiacus Sayed was recorded in Cairo, Giza, El- Fayoum and El - Menia governorate, Egypt infesting date palm fronds, preferring the upper leaf surface. In 2011, Al-Atawi, recorded $P$. aegyptiacus infesting vegetable crops (Ipomoea batatas and Solanum melongena) in three localities of Saudi Arabia.

The present investigation aimed to study the activity of $H$. coccophagus as a predator of $F$. phoenicis on the two varieties of date palm; Semany and Zaghlol as well as the tenuipalpid mite $P$. aegyptiacus as a pests of date palm on the previous varieties.

\section{MATERIALS AND METHODS}

Field study was conducted at Giza governorate to study role of $H$. coccophagus as a predator of the diaspidid, Fiorinia phoenicis and the tenuipalpid mite $P$. aegyptiacus infested two varieties (Semany and Zaghlol) of date palm trees. The period of study 
extended from mid April 2012 to mid May 2013. Half monthly samples of twenty five palm leaflets were picked randomly from five date palm trees in each variety of nearly the same age, height and growth vigor. One square inch of the middle portion of leaflet was selected and examined to determine the number of the diaspidid, $F$. phoenicis and the associated eggs, nymphs and adults of both mites during the period of study.

Half-monthly mean, max., min. temperatures and relative humidity were obtained from Meteorological Central Laboratory at Giza.

Statistical analysis: one-way ANOVA was performed to analyze the effect of date palm variety on the population of the prey, $F$. phoenicis and its predator, $H$. coccophagus.

Simple correlation " $r$ " was performed to study the relationship between the population of $F$. phoenicis and H. coccophagus in each variety.

\section{RESULTS AND DISCUSSION}

Field study was conducted on the predaceous mite, $H$. cocophagus, its prey $F$. phoenicis and the phytophagous mite, $P$. aegyptiacus on Semany and Zaghlol varieties of date palm trees at Giza governorate.

\section{1- F. phoenicis (as a prey of $H$. coccophagus) on Semany and Zaghlol:}

$F$. phoenicis population was presented all over the year, but in low population during the period from $1^{\text {st }}$ October to $1^{\text {st }}$ November ranging between 31.4 and 38.2 individuals / sq. inch on Semany and 37.4 and 40.4 individuals / sq. inch on Zaghlol (Fig.1). The associated averages of max., min., mean temperature and relative humidity were $27.8-32.0$, $18.8-21.3,23.3-26.7^{\circ} \mathrm{C}$ and $57.7-66.1 \%$ R.H. (Fig. 2).

High population of $F$. phoenicis was recorded from December 2012 until May 2013 that ranged between $70-98.6,83.8-102.2$ individuals / sq. inch on Semany and Zaghlol varieties respectively. The associated averages of max., min., mean temperature and relative humidity during the previous period showed highly differentiation as their records ranged between $19.5-37,7.2-21.2$, $14.1-29.1^{\circ} \mathrm{C}$ and $40.1-66.1 \%$ R.H. (Fig.2).

2- The hemisarcoptid predacious mite, $\boldsymbol{H}$. coccophagus:

Observations during laboratory investigation revealed that, nymphs and adults of $H$. coccophagus fed on adult females (Fig.4a) of the prey ( $F$. phoenicis) and not on the associated phytophagous mite, P. aegyptiacus. H. coccophagus adult deposited an average of $10-15$ eggs on the prey (Fig. 4b).

\section{H. coccophagus eggs on Semany and Zaghlol:}

During the period of study, data showed that, population of the predacious mite eggs, was presented in large numbers during April and May 2012, ranging 20.4- 27.8 eggs /sq. inch and $18.2-23.0$ eggs / sq. inch on Semany and Zaghlol, respectively (Fig.5). The associated averages of max., min., mean temperature and relative humidity were $29.4-34.1,16.4-20.4,22.9-27.3^{\circ} \mathrm{C}$ and $44.2-47.2 \%$ R.H. (Fig.2). While during April and May 2013, population of $H$. coccophagus eggs ranged $8.6-24.2$ eggs / sq. inch and $13.0-29$ eggs / sq. inch on the two previous varieties, respectively. The associated averages of max., min., mean temperature and relative humidity were 28.8 $37,15.2-21.2,22.1-29.1{ }^{\circ} \mathrm{C}$ and $40.1-49.2 \%$ R.H. (Fig.3). On the other hand, no eggs were recorded in October and on $1^{\text {st }}$ of November 2012 (Fig.5).

Total average of $H$. coccophagus eggs during all over the period of study was 7.5 and $8.1 \mathrm{eggs} / \mathrm{sq}$. leaf inch of the two date palm varieties, respectively (Fig.3). No significant difference existed between records of the two varieties (Table 1).

In this concern, Attia et al., 2012b showed that; H. malus eggs on the diaspidid, Aulacaspis tubercularis increased gradually from January to reach its peak in May 2010 (87.3 eggs/ mango leaf) as the same of $H$. coccophagus on $F$. phoenicis and no eggs were deposited in September, October and November; while no eggs were deposited in October and $1^{\text {st }}$ November with $H$. coccophagus on $F$. phoenicis.

\section{$H$. coccophagus nymphs and adults on Semany and Zaghlol date palm varieties:}

During the period of study, population of nymphs and adults of $H$. coccophagus, was noted in large numbers from mid April to $1^{\text {st }}$ August 2012 as ranged 11.8-29 and 15-33.4 individuals / sq. inch on Semany and Zaghlol varieties, respectively. While these records ranged $6.4-19$ and $7.2-19.4$ individuals / sq. inch during March until May 2013 (Fig. 6).

Total average of $H$. coccophagus nymphs and adults during the whole period of study was 10.3 and 11.8 on Semany and Zaghlol, respectively (Fig.3). Significant difference existed between records of the two varieties (Table1). 


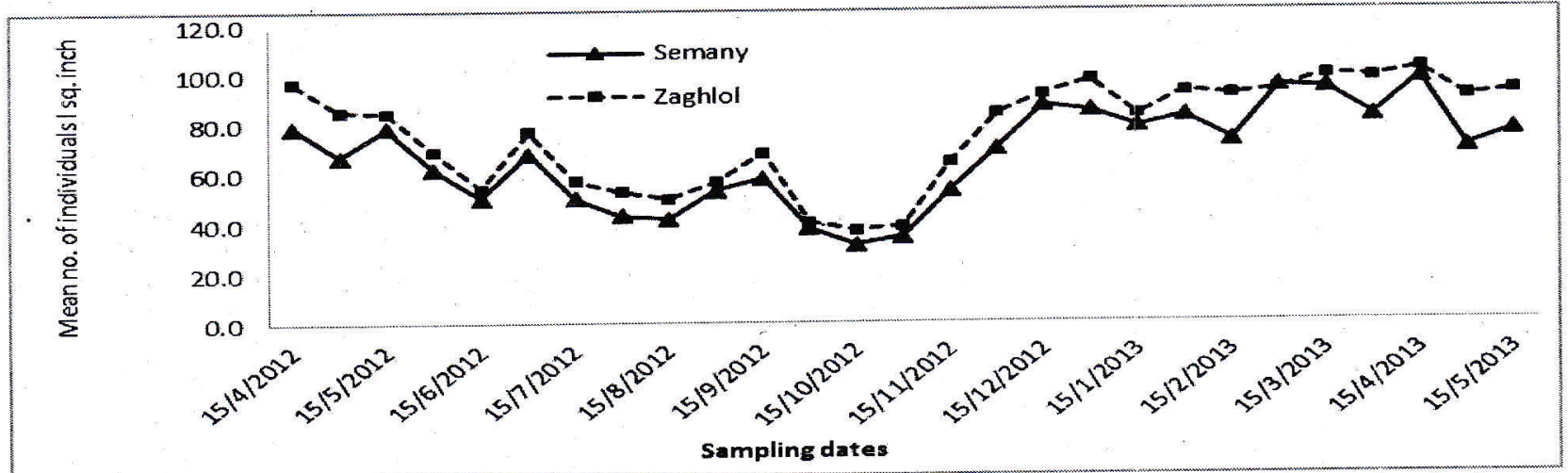

Fig. (1): Mean no. of $F$. phoenicis population infested Semany and Zaghlol varieties of date palm during the period of study at Giza governorate.

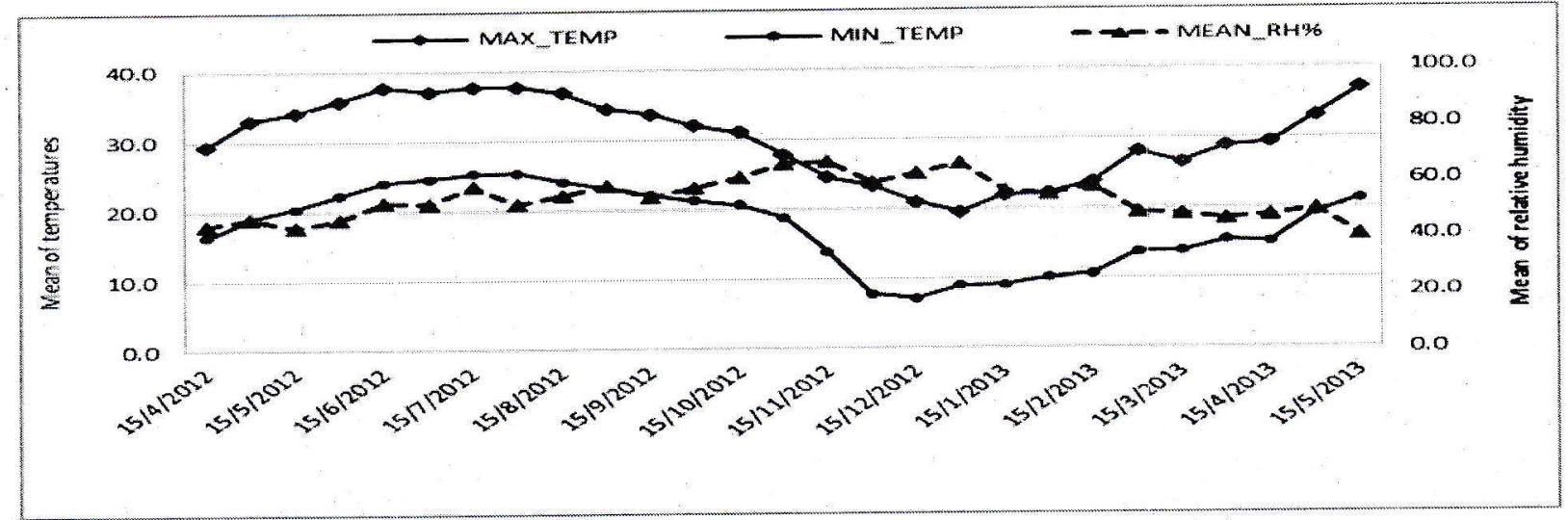

Fig. (2): Half monthly means of temperature and relative humidity during the period of study at Giza governorate.

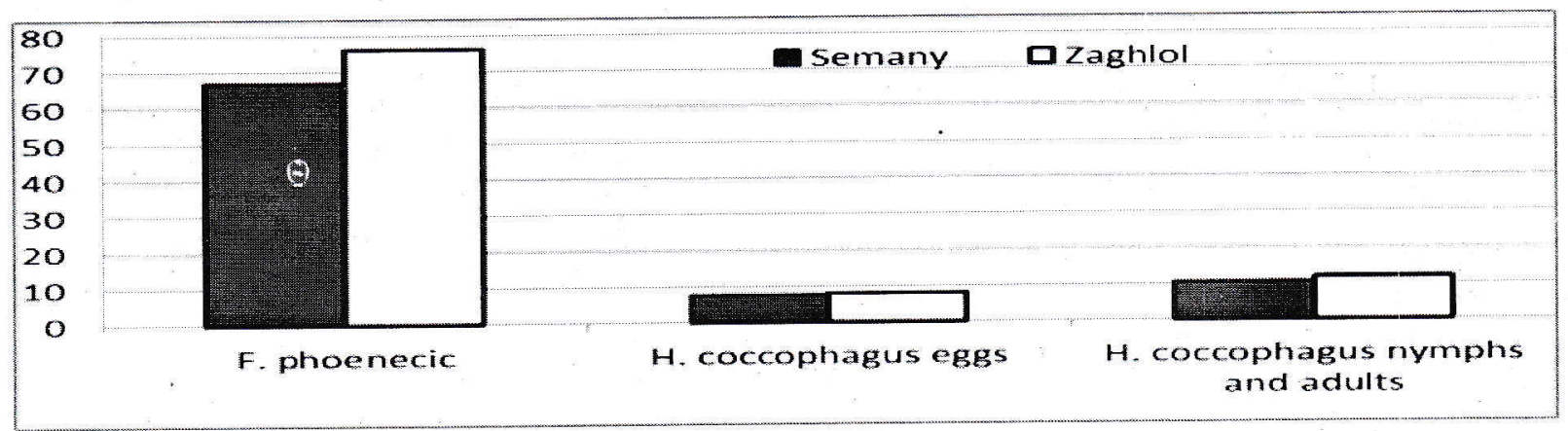

Fig.(3): Comparison between total average population of $F$. phoenicis and H. coccophagus on Semany and Zaghlol varieties of date palm at Giza governorate.

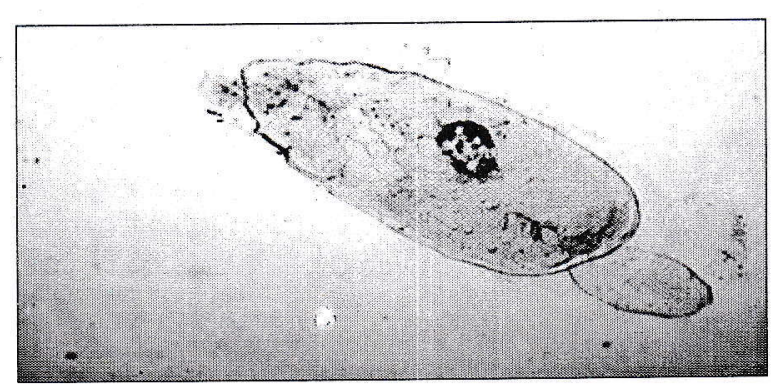

Fig.(4a): Ovipositing adult female of $F$. phoenicis containing adult female of $H$. coccophagus.

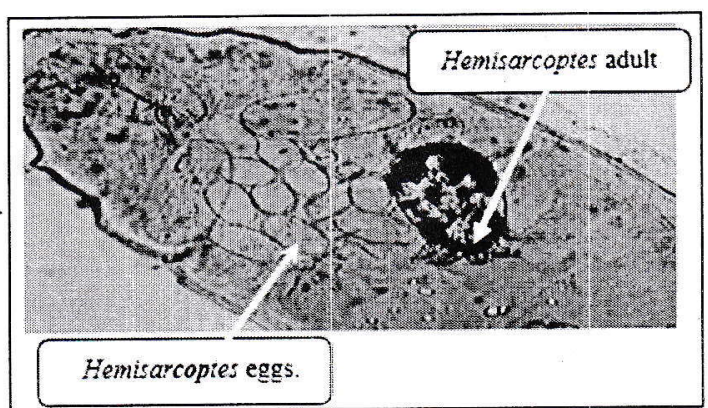

Fig.(4b): Adult and eggs of $H$. coccophagus deposited on F.phoenicis ovipositing adult female. 


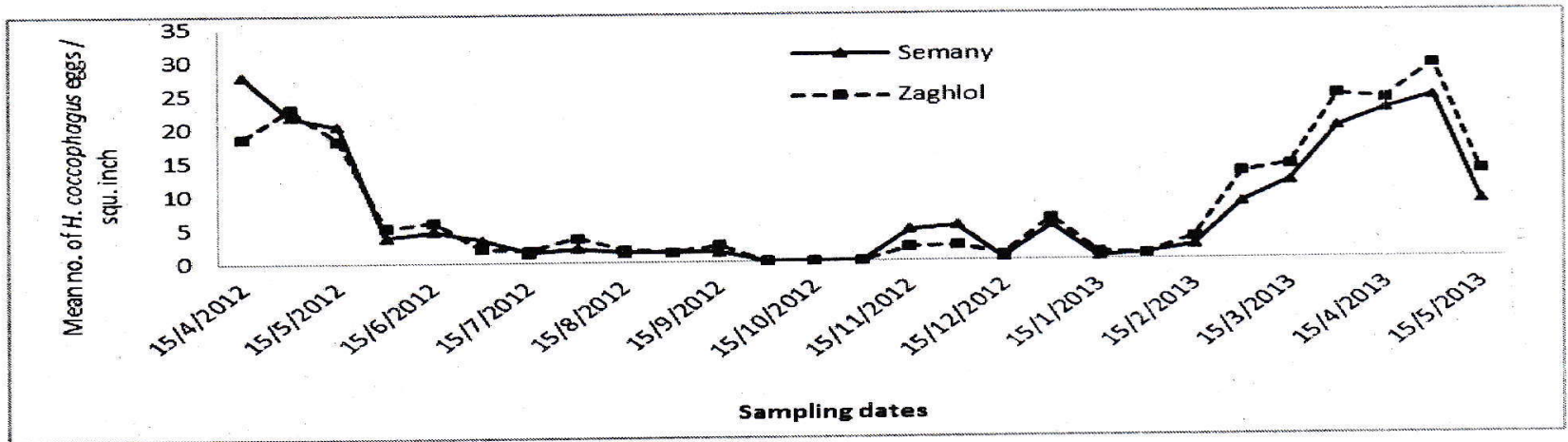

Fig. (5): Mean no. of $H$. coccophagus eggs on Semany and Zaghlol date palm varieties during the period of study at Giza governorate.

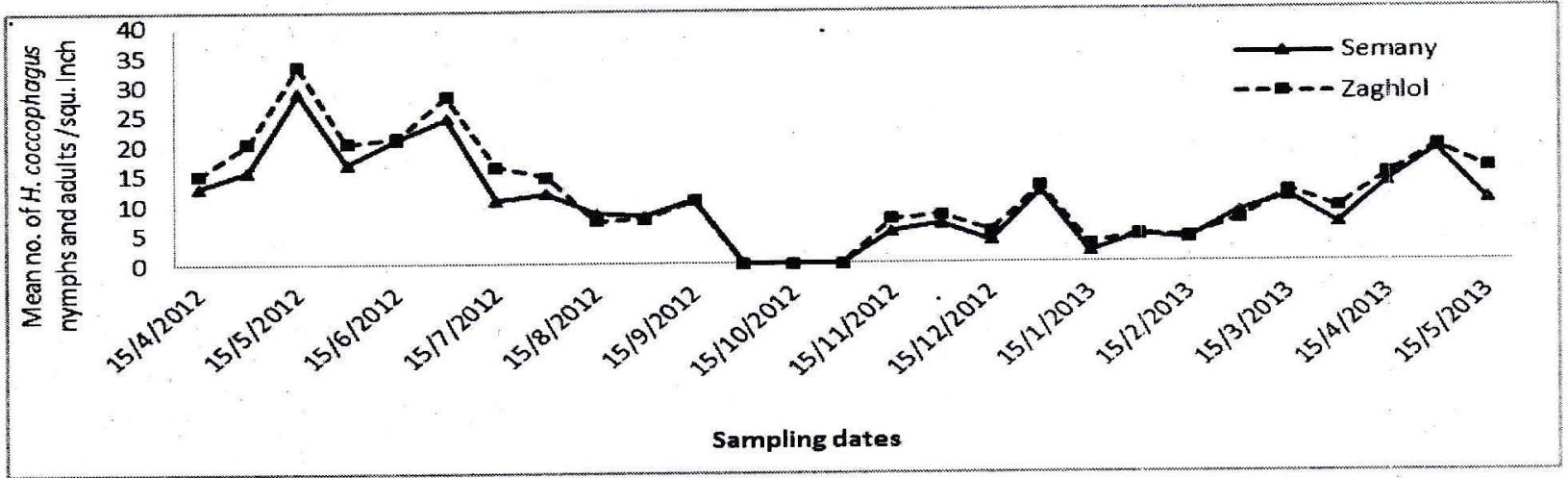

Fig.(6): Mean no. of $H$. coccophagus nymphs and adults on Semany and Zaghlol varieties of date palm during the period of study at Giza governorate.

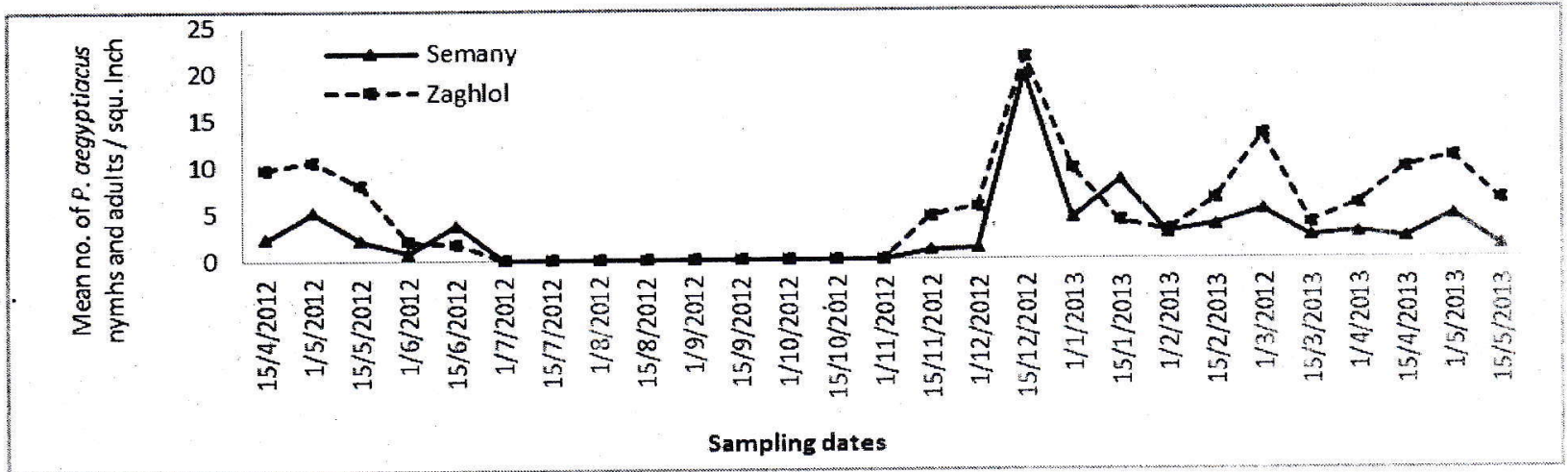

Fig. (7): Mean no. of $P$. aegyptiacus eggs on Semany and Zaghlol varieties of date palm during the period of study at Giza governorate.

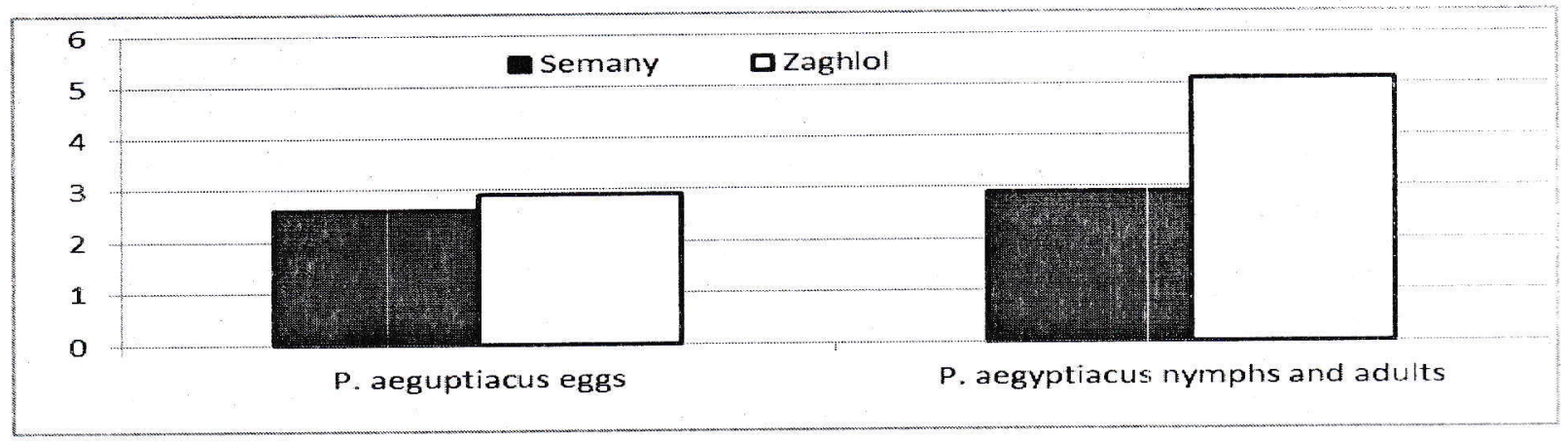

Fig.(8): Comparison between total average population of $P$. aegyptiacus on Semany and Zaghlol varieties of date palm at Giza governorate. 


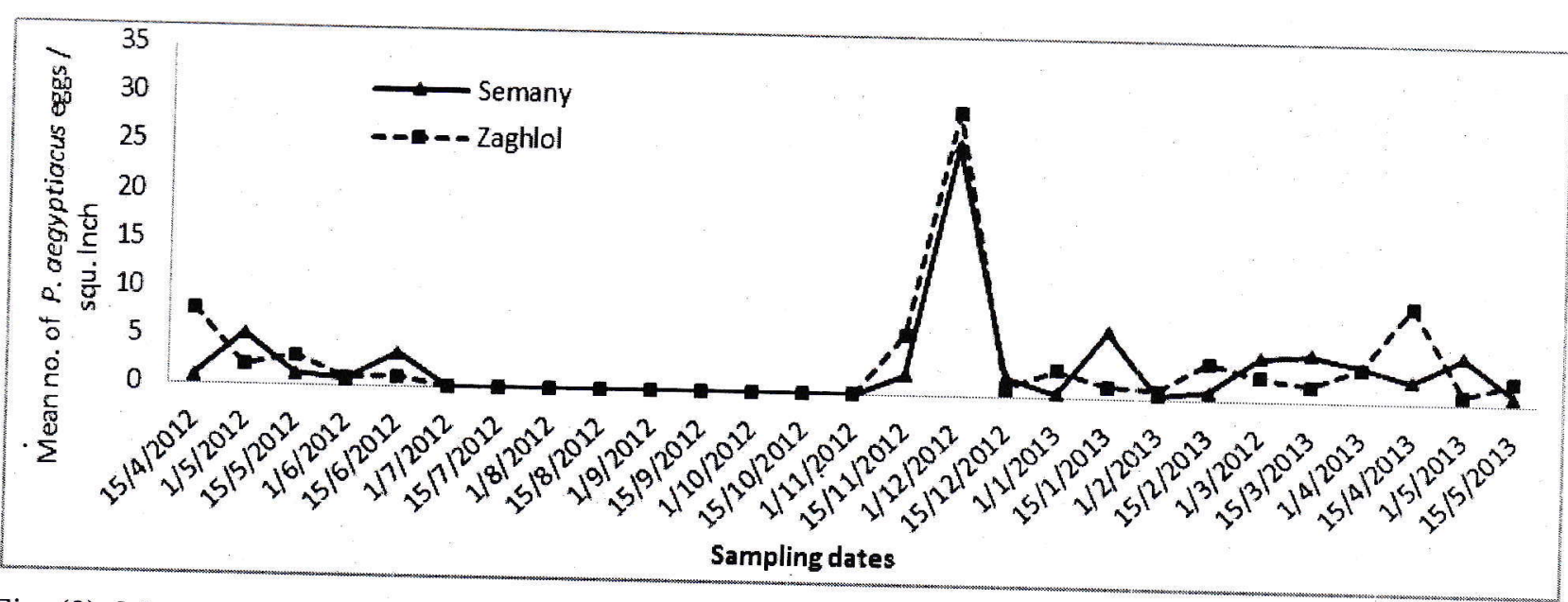

Fig. (9): Mean no. of P.aegyptiacus nymphs and adults on Semany and Zaghlol varieties of date palm at Giza
Governorate.

Table (1): Analysis of records reported for mean number of the prey $F$. phoenicis and its predator H.coccophagus eggs, nymphs and adults during the period of study.

\begin{tabular}{|c|c|c|c|c|c|c|c|}
\hline Occurrence period & $\frac{c e \text { period }}{\text { to }}$ & \multicolumn{2}{|c|}{$\begin{array}{l}\text { F. phoenicis and } \\
\text { H. coccophagus }\end{array}$} & \multirow{2}{*}{$\begin{array}{c}\text { Variable } \\
\text { date palm variety } \\
\text { Zaghlol } \\
\end{array}$} & Mean \pm SE & F. value & $\begin{array}{c}\text { LSD } \\
5 \%\end{array}$ \\
\hline \multirow{4}{*}{$15 / 4 / 2012$} & \multirow{4}{*}{$15 / 5 / 2013$} & The prey & F.phoenicis & & 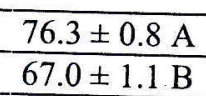 & $47.76^{* *}$ & 2.3 \\
\hline & & \multirow{3}{*}{$\begin{array}{l}\text { The } \\
\text { predacious } \\
\text { mite }\end{array}$} & H. coccophagus & Zaghlol & $8.05 \pm 0.2 \mathrm{~A}$ & \multirow[b]{2}{*}{38.04} & \multirow[b]{2}{*}{1.11} \\
\hline & & & eggs & Semany & $7.50 \pm 0.2 \mathrm{~A}$ & & \\
\hline & & & H. coccophagus & Zaghlol & $-11.83 \pm 0.3 \mathrm{~A}$ & $62.27 *$ & 078 \\
\hline
\end{tabular}

Table (2): Monthly means of F. phoenicis and H. coccophagus populations in each variety of date palm associated with temperature and relative humidity at Giza governorate.

\begin{tabular}{|c|c|c|c|c|c|c|c|c|}
\hline \multirow{2}{*}{$\begin{array}{l}\text { Sampling } \\
\text { dates }\end{array}$} & \multicolumn{2}{|c|}{ Semany Variety } & \multicolumn{2}{|c|}{ Zaghlol variety } & \multirow{2}{*}{$\begin{array}{l}\text { Max. } \\
\text { Temp. }\end{array}$} & \multirow{2}{*}{$\begin{array}{l}\text { Min. } \\
\text { Temp. }\end{array}$} & \multirow[b]{2}{*}{$\begin{array}{l}\text { Mean } \\
\text { Temp. }\end{array}$} & \multirow{2}{*}{$\begin{array}{l}\text { Mean } \\
\text { RH\% }\end{array}$} \\
\hline & $F$. phoenicis & H. coccophagus & F. phoenicis & H. coccophagus & & & & \\
\hline May 2012 & 73.2 & 22.3 & 85.5 & 26.9 & 33.6 & 19.7 & 26.7 & 45.7 \\
\hline June 2012 & 56.6 & 18.9 & 61.9 & 20.9 & 36.8 & 23.2 & 30.0 & 49.9 \\
\hline July 2012 & 59.4 & 17.7 & 67.5 & 22.3 & 37.4 & 25.0 & 31.2 & 55.7 \\
\hline Aug. 2012 & 42.8 & 10.2 & 51.7 & 10.9 & 37.3 & 24.8 & 31.1 & 53.8 \\
\hline Sep. 2012 & 55.8 & 9.4 & 62.7 & 9.1 & 34.1 & 22.7 & 28.4 & 56.6 \\
\hline Oct. 2012 & 34.8 & 0 & 38.9 & 0 & 31.6 & 21.0 & 26.3 & 59.5 \\
\hline Nov. 2012 & 43.9 & 2.7 & 51.7 & 3.7 & 26.2 & 16.4 & 21.3 & 66.5 \\
\hline Dec. 2012 & 78.9 & 5.2 & 88.3 & 6.7 & 22.1 & 7.5 & 14.8 & 60.9 \\
\hline Jan. 2013 & 82.3 & 6.9 & 90.9 & 8 & 20.7 & 9.1 & 14.9 & 61.2 \\
\hline Feb. 2013 & 78.4 & 4.3 & 92.7 & 4.6 & 23.0 & 10.4 & 16.7 & 56.5 \\
\hline March 2013 & 94.9 & 9.8 & 96.9 & 9.6 & 27.3 & 13.8 & 20.6 & 47.7 \\
\hline April 2013 & 90.8 & 10 & 100.5 & 12 & 29.1 & 15.3 & 22.2 & 44.8 \\
\hline May 2013 & 73.4 & 14.7 & 75 & 11.6 & 35.1 & 20.2 & 27.7 & 47.5 \\
\hline
\end{tabular}
Table (3): Analysis of records reported for mean number of eggs and nymphs with adults of $P$. aegyptiacus
during the period of study.

\begin{tabular}{|c|c|c|c|c|c|c|}
\hline \multicolumn{2}{|c|}{ Occurrence period } & \multirow{2}{*}{ Phytophagus mite } & \multirow{2}{*}{$\begin{array}{l}\text { Variable } \\
\text { date palm variety }\end{array}$} & \multirow[b]{2}{*}{ Mean $\pm \mathrm{SE}$} & \multirow[b]{2}{*}{ F. value } & \multirow[b]{2}{*}{$\mathrm{LSD} 5 \%$} \\
\hline From & to & & & & & \\
\hline \multirow{3}{*}{$15 / 4 / 2012$} & \multirow{4}{*}{$15 / 5 / 2013$} & P. aegyptiacus & Zaghlol & $2.95 \pm 0.06 \mathrm{~A}$ & \multirow{2}{*}{11.87} & \multirow[b]{2}{*}{1.18} \\
\hline & & eggs & Semany & $2.59 \pm 0.06 \mathrm{~A}$ & & \\
\hline & & \multirow{2}{*}{$\begin{array}{l}\text { P. aegyptiacus } \\
\text { nymphs and adults }\end{array}$} & Zaghlol & $5.05 \pm 0.06 \mathrm{~A}$ & \multirow{2}{*}{$8.13^{* *}$} & \multirow{2}{*}{1.25} \\
\hline with th & & & Semany & $2.75 \pm 0.08 \mathrm{~B}$ & & \\
\hline
\end{tabular}


In this concern, Attia et al., 2012b showed that, the largest population of $H$. malus nymphs and adults on $A$. tubercularis occurred from April to June and peaked in May; while Ji et al., 1991 mentoined that, the largest population of the predator, Hemisarcoptes sp. on Lepidosaphus salicina occurred from mid June to late August; this difference might be due to prey, locality and condition differences.

Generally, the population of $F$. phoenicis and its associated predator $H$. coccophagus was affected by the variety of date palm as Zaghlol variety was the favourate.

Relationship between population of the predaceous mite and its prey on each variety of date palm:

Obtained monthly data (Table 2 ) showed that, the highest population of $H$. coccophagus was $22.3,26.9$ individuals / sq. inch when prey population was $73.2,85.5$ individuals / sq. inch in May 2012 on date palm Semany and Zaghlol varieties, respectively. The associated averages of max., min., mean temperature and relative humidity were $33.6,19.7$, $26.7^{\circ} \mathrm{C}$ and $45.7 \%$ R.H.

Thereafter the population of the mite decreased gradually until Sep. 2012 to 9.4 and 9.1 individuals / sq. inch when its prey population recorded 55.8, 62.7 individuals / sq. inch on the two previous varieties, respective!y. In September 2012 the associated averages of max., min., mean temperature and relative humidity were $34.1,22.7,28.4{ }^{\circ} \mathrm{C}$ and $56.6 \%$ R.H.

In October 2012, no individuals of the predacious mite was recorded when the population of the prey was 34.8 and 38.9 individuals / sq. inch on Semany and Zaghlol varieties. The associated averages of max., min., mean temperature and relative humidity were $31.6,21.0,26.3^{\circ} \mathrm{C}$ and $59.5 \%$ R.H. After that, the mite population increased gradually from November 2012 (2.7, 3.7 individuals / sq. inch in the two respective varieties) and reached its highest population in May 2013 (14.7 individuals / sq. inch) when its prey population was 73.4 individuals / sq. inch on Semany variety; while was in April 2013 (12.0 individuals / sq inch) when its prey population was 100.5 individuals / sq. inch on Zaghlol variety.

Generally the temperature and relative humidity did not show correlation with population of the mite.

Correlation coefficients analysis between records of $F$. phoenicis and $H$. coccophagus population in each variety showed no significant correlation when the value of (r) was 0.180 and 0.219 in Semany and Zaghlol, respectively.

\section{3- The tenuipalpid mite, Phyllotetranychus aegyptiacus \\ P. aegyptiacus eggs on Semany and Zaghlol varieties}

During the period of study, the largest numberof eggs were presented on $1^{\text {st }}$ of December on Semany and Zaghlol (25.8 and 29.2 eggs / sq. inch, respectively); while no eggs were presented during the period from $1^{\text {st }}$ of July until $1^{\text {st }}$ of November (Fig. 7). Total average of $P$. aegyptiacus eggs during the whole period of study was 2.5 and 2.9 eggs / sq. inch on the two varieties respectively (Fig. 8). No significant differences existed between such records as the value of LSD 5\% was 1.18 (Table 3).

\section{P. aegyptiacus nymphs and adults on Semany and Zaghlol varieties: \\ During the period of study, the largest number of} nymhs and adults of $P$. aegyptiacus was recorded in mid - December on Semany and Zaghlol (19.8 and 21.6 individuals / sq. inch, respectively. Population of nymphs and adults of $P$. aegyptiacus ranged from $1.4-8.4$ to $3-13.2$ individuals / sq. inch during the period from January to May 2013. On the other hand no individuals were recorded during the period from July to mid - November (Fig. 11). Total average of $P$. aegyptiacus nymphs and adults during all period of study was 2.7 and 5.1 individuals / sq. inch on Semany and Zaghlol, respectively (Fig.10). Highly significant difference existed between records of the two varieties when the value of LSD $5 \%$ was 1.25 (Table 3 ).

\section{REFERENCES}

Al- Atawi, F. J. 2011. Phytophagous and predaceous mites associated with vegetable crops from Riyadh, Saudi Arabia. Saudi Journal of Biological Science, 18: 239 - 246.

Attia, Angel R. 2012. Seasonal activity of Pteroptrix aegyptica Eveans \& Abd-Rabou that parasitizing Fiorinia phoenicis Blachowsky (Hemiptera : Diaspididae) on date palm at Qalubyia Governorate, Egypt. Egypt. J. Agric. Res., 90 (2): $511-525$.

Attia, Angel R.; Mariam A. El Sanady and Sawsan G. Radwan 2012. Studies on the predaceous mites associated with the scale insects infesting mango trees at Qalubyia governorate, Egypt. Egypt. J. Agric. Res., 90 (2): 493 -509.

Elwan, E. A.; Maha I. El-Sayed and A. M. Serag. 2011. Seasonal activity of fiorinia date scale, 
Fiorinia phoenicis Balachowsky (Homoptera Diaspididae) on date palm at Giza governorate, Egypt. Egypt. J. Agric. Res., 89 (2):549-565.

Erol, T. and Yasar, B. 1999. Investigations on natural enemies, some biological characteristics and population fluctuation of Lepidosaphes ulmi (Homoptera: Diaspididae) and Palaecanium bituberculatum (Targ. And Tozz.) (Homoptera: Coccidae) harmful to apple trees in Van province. Turkish Journal of Agriculture \& Forestry, 23 (2) $151-164$.

Ghabbour, M. W. and Mohammad, Z. K. 2010. Fiorinia phoenicis (Hemiptera: Coccoidea: Diaspididae) new pest of palm trees in Egypt. J. Egypt. Ger. Soc. Zool., 58(E):15-20.

Hill, M.G.; Allan, D.J.; Henderson, R.C. and Charles, J.G. 1993. Introduction of armored scale predators and establishment of the predatory mite Hemisarcoptes coccophagus (Acari: Hemisarcoptidae) on latania scale, Hemiberlesia lataniae (Homoptera: Diaspididae) in Kiwifruit shelter trees in New Zealand. Bulletin of Entomological research, 83: $369-376$.

Izraylevish, S. and Gerson, U. 1993. Population dynamics of Hemisarcoptes coccophagus Meyer (Astigmata: Hemisarcoptidae) attacking three species of armored scale insects (Homoptera: Diaspididae). Experimental and Applied acarology, 17 (12): 877 - 888.

Ji; L. Z.; Yang, J.K. and Shao, Y. H. 1993. Life table study on Lepidosaphes salicina Bersch. Chinese
Journal of applied Ecology, 4(4): 454-455.

Kaufmann, T.1977. Hemisarcoptes sp. and biological control of the date palm scale, Parlatoria blanchardi Targioni. In the Sahel region of Niger. Environmental Entomology, 6: 882-884.

Radwan, S. G. 2012. Seasonal fluctuations of fiorinia date scale, Fiorinia phoenicis - Balachowsky (Hemiptera - Diaspididae) populations on dạte palm trees at Qalubyia governorate, Egypt. The Journal of Basic \& Applied Zoology, 65: 47 - 54.

Shimer, H. 1868. Notes on the Apple bark louse (Lepidosaphes conchiformis) with a description of a supposed new Acarus. Transactions of American Entomological Society, 1: 361-374.

Sorribas, J. J. and Garcia - Mari. F. 2008. Parasitism levels and species of natural enemies in field population of California red scale, Aonidiella aurantii (Hemiptera: Diaspididae) in Eastern Spain. IOBC/WPRS Bulletin, 38: 26-33.

Stathas, G.; Bouras, 'S. L.; Eliopoulos, P. A. and Emmanouel, N. G. 2005. Control of diaspidid scales on olive trees by releasing coccinelid predators. Bulletin OILB/, SROP, 28(9): $157-166$.

Zaher, M. A., 1984. Survey and ecological studies on phytophacus, predaceous and soil mites in Egypt. Programme U.S.A. Projet No. EG - ARS30. Grant No. FG - EG. 139 pp. 